\title{
O WLAŚCIWOŚCIACH UTWORU AUDIOWIZUALNEGO „JAKO CAŁOŚCI”
}

Problematyka utworu audiowizualnego, mimo 26 lat obowiazywania ustawy o Prawie autorskim i prawach pokrewnych z 4 lutego 1994 r. ${ }^{1}$, jest wciąż żywa. Można postawić tezę, że dynamika debaty wyznaczana jest z jednej strony zmianami przepisów i założeniem o konieczności prawidłowej ich wykładni, z drugiej zaś - interesami podmiotów, których celem jest eksploatacja utworów audiowizualnych i czerpanie z tego tytułu korzyści (np. operatorów sieci kablowych). Jednym z kontrowersyjnych zagadnień okazuje się pojmowanie samego utworu audiowizualnego, ponieważ można go postrzegać zarówno jako określoną całość zdatną do odbioru przez widza, jak i z perspektywy procesu powstawania, w którym pojawiają się poszczególni twórcy z wkładami twórczymi i towarzyszącymi im prawami autorskimi.

Należy podkreślić, że nie jest celem tego artykułu ani kompleksowe przedstawienie bogatej i złożonej problematyki związanej z prawnoautorskim statusem utworu audiowizualnego, ani też ukazanie jej na tle zagranicznych rozwiązań prawnych. Jak stwierdza się bowiem od lat w doktrynie prawa autorskiego, „ustawa reguluje problematykę autorską w sposób autonomiczny i oryginalny”2.

\section{UTWÓR AUDIOWIZUALNY - PODEJŚCIE TEORETYCZNE}

Truizmem jest twierdzenie, iż widz postrzega utwór audiowizualny, w tym film, jako zwartą całość. Dla takiego poglądu można znaleźć usprawiedliwienie w piśmiennictwie z zakresu teorii filmu. Przykładowo Janusz Plisiecki jest zdania, że: „Film kształtuje nastawienie na łączne wydobycie aspektów audialnych i wizualnych oraz na scalanie ich w spójną całość znaczeniową. [...] Film oddziałuje za pomoca obrazów, układów linii i barw, poprzez dialogi i muzykę - wszystkie te środki i sposoby wypowiedzi są stosowane jednocześnie, jak-

${ }^{1}$ T.jedn.: Dz. U. 2019, poz. 1231 ze zm. (dalej jako: pr. aut.).

2 Zdaniem Błeszyńskiego (1998: 2): „dodać należy stwierdzenie, będące zapewne truizmem, jednak niestety potrzeba jego powtarzania okazuje się być nazbyt często koniecznościa, że ustawa reguluje problematykę autorską w sposób autonomiczny i oryginalny. Przy jej wykładni nie można mianowicie odwoływać się do ujęć poprzedniej ustawy o prawie autorskim z 10 lipca 1952 roku [...]. To samo odpowiednio dotyczy nazbyt nieraz pochopnie wyprowadzanych wniosków z częściowo podobnych do zawartych w ustawie rozwiązań pojawiających się w zagranicznych ustawach o prawie autorskim, a więc milczącego założenia, że pierwszeństwo przy interpretacji należy dawać rozwiązaniom stosowanym w innych rozwiniętych państwach europejskich, na których ponoć obowiązująca ustawa była wzorowana". 
by stopione w jedna całość”3. Można tu nawiąać do koncepcji „polifonicznego zestroju jakościowego” dzieła sztuki, polegającego na „wzajemnym zespoleniu wielu różnych jakości wewnętrznie zorganizowanych w spójną całość. Jakości nie istnieją tutaj autonomicznie, każda z nich ulega modyfikacji pod wpływem pozostałych jakości współwystępujących z nią w dziele. Wzajemne modulacje jakości mogą doprowadzić do wykształcenia się jakości zupełnie nowych [...]"4. Roman Ingarden rzeczywistość ekranową określa jako „ciąg lub strumień fotograficznie zrekonstruowanych wyglądów wzrokowych” ". Z kolei przy założeniu, że dzieło filmowe to „twór autonomiczny, integralny”, proponowano ujmowanie go jako „zbiór sygnałów wizualnych”6, czy „obraz dźwięczący”7. Marek Hendrykowski również zaznacza, że „Dzieło filmowe jest wypowiedzią syntetyczną”.

W społeczeństwie incydentalnie tylko, w związku z festiwalami i konkursami filmowymi, dostrzega się istnienie w tym utworze poszczególnych wkładów, a także ich twórców. Szczególnie jednak intensywnie odbiór utworu audiowizualnego wiązany jest z działaniami artystów wykonawców, następnie z reżyserem czy twórca muzyki. Odmiennie jednak kwestia ta przedstawia się w teorii filmu.

Zdaniem Hendrykowskiego: „Fakt, iż mówimy o autorstwie w aspekcie danego utworu jako całości, nie stanowi bynajmniej argumentu mogacego przesadzić o tym, iż autorski udział poszczególnych współtwórców filmu traci swoją autonomię i uzasadnienia na rzecz ogólnie rozumianego autorstwa owej całości. Innymi słowy, integralna jedność struktury utworu nie pozbawia poszczególnych twórców ich autorskich praw nie tylko do własnego wkładu, ale i do autorstwa całości dzieła. Wprost przeciwnie, autorstwo rozumiane jako funkcja staje się w pełni czytelne właśnie w relacji i w odniesieniu do owej całości" ${ }^{9}$. Autor dodaje, że: „Integralność końcowego efektu nie przeszkadza temu, że wewnątrz danej całości dostrzegamy także cząstkę indywidualnego wkładu: operatora, aktora, scenografa, kompozytowa itp. Kluczowe znaczenie przypada w tym względzie estetycznej zasadzie unitas multiplex. Kosmos dzieła filmowego [...] okazuje się uniwersum zorganizowanym na prawach jedności wielości i wielości w jedności. Filmowa całość nie byłaby tym, czym jest, bez swoistych elementów, które się na nią złożyły”10. Hendrykowski wyjaśnia, że: „Autor, rozumiany jako konkretny podmiot twórczy, jest w filmie z reguły autorem zbiorowym - uosabianym przez wieloosobowy zespół, z którym każdy pełni określoną rolę. Partyturowy model struktury tworzywowej i językowej utworu filmowego ma swój funkcjonalny odpowiednik w wielości kreujących go podmiotów sprawczych"11.

3 Plisiecki (2005): 14, 25.

${ }^{4}$ Nowak-Gruca (2018: 175) odwołuje się do koncepcji Ingardena (1966: 142) dotyczących dzieła literackiego.

${ }^{5}$ Ingarden (1952): 305.

${ }^{6}$ Ledóchowski (1966): 79, 11.

7 Bocheńska (1966): 197, 11.

8 Hendrykowski (1991): 15.

9 Hendrykowski (2014): 308.

10 „Nasze odbiorcze przypuszczenia na temat wielkości autorskiego udziału poszczególnych twórców w danym filmie nie są niczym więcej niż hipoteza, u której źródła leży tajemnica twórczości dająca impuls fascynacji wszelką sztuką" (Hendrykowski 1988: 41).

11 Hendrykowski (1991): 15-16. 
Trudno jednoznacznie ocenić, brak bowiem na to wystarczających dowodów w treści uzasadnień orzeczeń, czy w ogóle i ewentualnie jak dalece poglądy prezentowane w teorii filmu są brane pod uwagę w orzecznictwie z zakresu prawa autorskiego. Natomiast lakoniczne podejście niektórych sądów do utworu audiowizualnego obrazuje wyrok Sądu Apelacyjnego w Katowicach z 28 grudnia 2017 r., stwierdzający na tle art. $70^{1}$ ust. 1 pr. aut., że: „Utwór audiowizualny jest traktowany jako całość, a nie suma utworów wkładowych"12. Z kolei w doktrynie w szczególności do poglądów Marka Hendrykowskiego odwołują się Piotr Ślęzak ${ }^{13}$, Dorota Sokołowska ${ }^{14}$ i Agnieszka Damasiewicz ${ }^{15}$ i Ksenia Kakareko ${ }^{16}$.

Niekiedy z kolei to teoretycy filmu konfrontuja swoje tezy z poglądami doktryny prawa autorskiego. Hendrykowski ${ }^{17}$ mianowicie uważa „za słuszny i w pełni zasadny” wyrażony przez Jana Błeszyńskiego pogląd, iż „utwór audiowizualny powinien być oceniany zarówno z perspektywy jego twórcy (współtwórców), jak i z perspektywy twórców utworów wkładowych"18.

\section{UTWÓR AUDIOWIZUALNY „JAKO CALOŚĆ” W DOKTRYNIE I ORZECZNICTWIE PRAWA AUTORSKIEGO}

Jednym z poglądów wpływających na stanowisko doktryny i orzecznictwa jest błędna teza wyrażona w wyroku SN z 3 stycznia 2007 r. ${ }^{19}$, iż utwór audiowizualny stanowi całość, jest jednym utworem, a nie zbiorem różnych utworów tzw. wkładowych. Teza ta niestety jest w wyrokach sądowych często powielana ${ }^{20}$.

Przykładem reprezentatywnym w tym zakresie jest nietrafny wyrok Sadu Apelacyjnego w Warszawie z 7 lutego 2014 r. ${ }^{21}$ Mianowicie Sąd nie zgadza się z poglądem, iż obok autorskich praw majątkowych do utworu audiowizualnego jako całości, twórcom utworów wkładowych przysługują równolegle prawa do poszczególnych utworów, wchodzących w skład utworu audiowizualnego. W konsekwencji Sąd sprzeciwia się tezie, by podczas eksploatacji utworu audiowizualnego jako całości, np. w drodze nadawania, dochodziło jednocześnie do eksploatacji poszczególnych utworów wkładowych. Według Sądu „nie wydaje się, aby zamiarem ustawodawcy było takie uregulowanie majątkowych praw autorskich, aby prawa do utworu audiowizualnego dublowały się. Do takich konsekwencji prowadziłoby zaś przyjęcie, że obok prawa do utworu audiowizualnego jako integralnej całości funkcjonuje zestaw praw do utworów wkładowych eksploatowanych w ramach utworu audiowizualnego, a eksplo-

12 I ACa 698/17, Lex nr 2446537.

${ }^{13}$ Ślęzak (2008): 86-87.

${ }^{14}$ Sokołowska (2011).

${ }^{15}$ Damasiewicz (2015).

${ }^{16}$ Kakareko (2019), np. s. 208.

${ }^{17}$ Hendrykowski (2014): 308.

${ }^{18}$ Błeszyński (2009): 14.

${ }^{19}$ Wyrok SN z 3 stycznia 2007 r., IV CSK 303/06, Lex nr 255587.

${ }^{20}$ Por. np. wyrok NSA z 19 lutego 2015 r., II OSK 1764/13, Lex nr 1772425; wyrok SN z 17 września 2014 r., I CSK 621/13, Lex nr 1537547.

${ }^{21}$ Wyrok SA w Warszawie z 7 lutego 2014 r., I ACa 452/13, Lex nr 1483873. 
atacja utworu audiowizualnego oznacza równoczesną eksploatację każdego z utworów wkładowych”. Dodatkowo SA wywodzi, że w przypadku innych utworów współautorskich „nie jest podnoszone, aby przysługiwały do nich dwa naraz zestawy praw autorskich":

- po pierwsze, prawo zespołu wszystkich współtwórców do tego utworu,

- po drugie, prawa tych spośród nich, których wkłady dałyby się wyodrębnić z całego dzieła współautorskiego.

Zdaniem SA, jeżeli chodzi o utwory słowne, muzyczne, słowno-muzyczne itd. zawarte w utworze audiowizualnym, to dana organizacja zbiorowego zarządzania prawami autorskimi ma uprawnienie do zarządzania prawami autorskimi do tych utworów funkcjonujacych w ramach utworu audiowizualnego o tyle tylko, o ile nie jest to sprzeczne z koncepcja, że utwór audiowizualny stanowi jedno dzieło, do którego prawa autorskie przysługują producentowi. Sąd stanowczo argumentuje, że utwór audiowizualny ma charakter utworu współautorskiego, o którym mowa w art. 9 pr. aut. Utwór audiowizualny stanowi zatem jedna integralną całość, nie zaś zbiór utworów wkładowych, a przy tym jest czymś więcej niż prostą sumą utworów, które się nań składają. Przeciwne stanowisko opiera się zaś na niesłusznym, w ocenie Sądu, założeniu, że obok autorskich praw majątkowych do utworu audiowizualnego jako całości, twórcom utworów wkładowych przysługują równolegle prawa do poszczególnych utworów, wchodzacych w skład utworu audiowizualnego.

Powyższy wyrok jest przykładem na to, jak bardzo przyjmowanie kolejnych błędnych założeń może prowadzić do ostatecznego chybionego wniosku. Jednym bowiem z pierwszych założeń Sądu było uznanie, że utwór audiowizualny jest zawsze i wyłącznie oparty na współtwórczości.

W doktrynie w tym zakresie stanowczy i zarazem bardzo daleko idacy pogląd formułują Janusz Barta i Ryszard Markiewicz, stwierdzając, że: „Autorskie prawo majątkowe do utworu audiowizualnego powstaje w sposób pierwotny na rzecz współtwórców, i to zarówno do całości tego dzieła, jak i do utworów w nim usytuowanych" 22 . Pogląd ten nie znajduje jednak uzasadnienia w przepisach pr. aut., a tym bardziej nie można go poprzeć obserwacją faktów (rzeczywistości), będących źródłem ustalenia każdego utworu.

Utwór audiowizualny może mieć bowiem charakter mieszany, hybrydalny i w zależności od okoliczności faktycznych mogą w nim przeważać elementy współtwórczości (rozłącznej i nierozłącznej), cechy utworu zbiorowego, względnie przejawy utworów połączonych, zbiorów utworów, opracowań czy inspiracji, przy czym nie jest uzasadnione rozpatrywanie konstrukcji utworu audiowizualnego w płaszczyźnie horyzontalnej (co dominuje przy współtwórczości), ponieważ ze względu na wielowątkowość i rozłożenie w czasie powstawania utworu audiowizualnego jego struktura ma naturę wertykalna, gdzie u podstawy rodzących się stosunków prawnych leży niechroniony prawem autorskim pomysł powstania utworu ${ }^{23}$. W zupełności zaś przyjmowanie na gruncie art. 69 pr. aut. poglądu o „obligatoryjnie ustawowym” współtwórczym charakterze utworu audiowizualnego nie może implikować stosowania go do poszczególnych wkładów,

22 Barta, Markiewicz (2016): 320.

23 Sokołowska (2011): 73; Sieńczyło-Chlabicz, Banasiuk (2011): 95; Sokołowska (2015): 92-93. 
które powstają generalnie na skutek indywidualnych aktów twórczych, w konkretnych tylko stanach faktycznych uzasadniających współtwórczość pomiędzy identyfikowanymi in casu osobami. Zatem co najwyżej można przyjąć, że w powołanym powyżej poglądzie Barty i Markiewicza przyznano, iż pomimo istnienia utworu audiowizualnego „jako całości”, można nadal identyfikować w nim utwory wkładowe i dociekać przynależnych doń praw autorskich.

\section{RELACJA POMIĘDZY WKŁADAMI TWÓRCZYMI A UTWOREM AUDIOWIZUALNYM „JAKO CALOŚCIĄ”}

Pewną emanację postrzegania utworu audiowizualnego w taki sposób, jak czynione to jest $\mathrm{w}$ teorii filmu, można jednak zauważyć także w najnowszym piśmiennictwie. Zdaniem Jana Błeszyńskiego, Marii Błeszyńskiej-Przybylskiej i Michała Błeszyńskiego: „W wyniku procesu powstawania utworu audiowizualnego powstaje odrębny utwór, stanowiący jednolitą i wielowarstwową całość zdatną do odrębnej eksploatacji. Jej znamienną cechą jest, że poszczególne utwory wkładowe, tworzone sukcesywnie na potrzeby produkcji audiowizualnej lub wykorzystywane na potrzeby tej produkcji utwory wcześniej powstałe sa wykorzystane w całości lub w części w postaci oryginalnej lub w postaci opracowań i składają się na utwór audiowizualny w wyniku noszącej znamiona twórcze ich synchronizacji w artystyczną całość" ${ }^{24}$. Jednocześnie jednak, zdaniem autorów, „utwór audiowizualny stanowi odrębny utwór w stosunku do utworów wkładowych"25. Zreszta już w 1995 r., zdaniem Błeszyńskiego, nie budziło wątpliwości, „że prawo do utworu audiowizualnego, jako całości odrębnej od wkładów powstajacych lub wykorzystywanych w fazie tworzenia utworu audiowizualnego, nie unicestwia praw do poszczególnych składników na jego potrzeby stworzonych lub w nim jedynie wykorzystanych w wersji oryginalnej lub w opracowaniu, o ile oczywiście spełniają wymogi stawiane utworom" ${ }^{26}$.

Podobnie Małgorzata Świętczak, analizując utwór audiowizualny, stwierdza, że: „Jego złożona, heterogeniczna struktura mieści w sobie zróżnicowane rodzajowo wkłady, stopione, zespolone w jedną nowa, odrębną całość”27. Gdy zaś chodzi o twórcze wkłady do utworu audiowizualnego, to mamy do czynienia z eksploatacja „utworów w utworze”, wobec czego: „Za niekwestionowana należy uznać zasadę podwójnej ochrony tego rodzaju wkładów - raz jako samoistnych utworów, innym razem jako komponentów innej, swoistej, odrębnej całości”, przy czym stanowi ona „jedność, odrębną jakość od prostej sumy zespolonych w nim wkładów"28.

Należy jednak zaznaczyć, że istnieje również całkowicie przeciwstawne ujęcie tej problematyki, mianowicie że utwór audiowizualny ,jest dziełem

${ }^{24}$ Błeszyński, Błeszyńska-Przybylska, Błeszyński (2019): 57.

25 Błeszyński, Błeszyńska-Przybylska, Błeszyński (2019): 57-58, z powołaniem się na wyrok SA w Warszawie z 17 sierpnia 2017 r., I ACa 837/16.

${ }^{26}$ Błeszyński (1995): 3.

27 Świętczak 2019): 1063.

28 Świętczak (2019: 1063-1064, 1077) odwołuje się w szczególności do uchwały 7 sędziów SN z 9 lutego 1968 r. (zasady prawnej), III CZP40/67, Lex nr 814. 
współautorskim, które stanowi strukturalną całość, a co za tym idzie - brak jest podstaw do dublowania się praw do jednego, choć mającego wielu autorów utworu" 29 . Szczególnie Monika Czajkowska-Dąbrowska broni poglądu, iż: „W przypadku jakiegokolwiek utworu współautorskiego innego niż dzieło audiowizualne nikt nie twierdzi, że przysługują w stosunku do niego dwa naraz »zestawy« praw autorskich: po pierwsze, prawo zespołu wszystkich współtwórców, a po drugie, prawa tych spośród nich, których wkłady dałyby się wyodrębnić z całego dzieła współautorskiego. Dlaczego akurat w przypadku dzieła audiowizualnego miałoby dochodzić do dublowania się praw do jednego, choć mającego wielu autorów utworu?" 30 .

Odpowiadając na to pytanie, można w pierwszej kolejności krótko skonstatować: bo taka jest wola ustawodawcy wyrażona w treści przepisów.

Z kolei dalsza refleksja może prowadzić do analogicznych pytań i udzielania różnych odpowiedzi odnośnie do konstrukcji utworu zbiorowego, bazy danych czy utworów połączonych. W każdym z tych przypadków dochodzi lub może dochodzić do synchronizacji wysiłków twórczych co najmniej dwóch osób, jednak nie zawsze ustawodawca przewiduje konsekwencje w postaci pojawienia się tzw. całości (utwory połaczone), czy przyznania autorskich praw majątkowych „do całości” innemu podmiotowi, niż twórcy utworów wkładowych (utwór zbiorowy). Idąc dalej - nie zawsze wymieniona w art. 11 pr. aut. encyklopedia będzie miała charakter utworu zbiorowego w rozumieniu tego przepisu. Nie ma przecież żadnych przeszkód faktycznych czy prawnych, by była stworzona wyłacznie przez jedną osobę albo by stanowiła utwór oparty na współtwórczości. Podobnie utwór audiowizualny jako rezultat określonego procesu twórczego, zważywszy na okoliczności powstawania, nie zawsze będzie nosił znamiona „idealnej”, i to wyłącznie - współtwórczości ${ }^{31}$. Zatem odnoszenie się w analizie sytuacji prawnej utworu audiowizualnego li tylko do współtwórczości może prowadzić do wniosków, które będą pozostawać w oczywistej sprzeczności z przepisami rozdz. 6 ustawy o pr. aut., a zwłaszcza do upadku ratio legis tej szczególnej regulacji.

Autonomia poszczególnych utworów znajdujących się w utworze audiowizualnym nie będzie przekreślona nawet w przypadku przyjęcia, że niektórzy z twórców utworów wkładowych tworzyli w warunkach współtwórczości. To stwierdzenie z kolei może prowadzić do interpretacji art. 69 pr. aut., stanowiącego definicję zakresową niepełną.

\section{WPLYW WYKLADNI ART. 69 PR. AUT. NA SYTUACJĘ PRAWNĄ UTWORÓW WKŁADOWYCH}

Artykuł 69 pr. aut. poddała badaniu na gruncie derywacyjnej koncepcji wykładni prawa Agnieszka Choduńn ${ }^{32}$. Autorka zaznacza na wstępie, że ce-

${ }^{29}$ Tak Bukowski (2015): 923; Czajkowska-Dąbrowska (2011): 431.

${ }^{30}$ Czajkowska-Dąbrowska (2011): 431.

31 Np. Bukowski (2015: 923) stanowczo utrzymuje, że „utwór audiowizualny został ukształtowany jako dzieło współautorskie, czemu wyraz daje art. 69” oraz że prawo do utworu audiowizualnego jako całości „powstaje w sposób pierwotny na rzecz ich współtwórców”.

32 Choduń (2018): 208-209. 
chą definicji zakresowej niepełnej jest to, że zawarte w niej wyliczenie to nie „wyliczenie przykładowe, ale wyliczenie wyczerpujace "na dziśs i jednocześnie otwarte "na przyszłość", wobec czego definicja taka w momencie jej redagowania nie ma „charakteru otwartego umożliwiającego swobodne włączanie niewymienionych w definiensie elementów do zakresu nazwy występującej w definiendum". Celem umieszczenia definicji zakresowej niepełnej w tekście aktu prawnego jest w myśl premii lex iubet non docent „nakaz rozumienia definiowanego wyrazu czy wyrażenia w określony sposób, a nie edukowanie poprzez podawanie przykładów"33.

Zdaniem Chodun „Błędem interpretacyjnym jest zatem włączanie do zakresu nazwy definiowanej za pomocą definicji zakresowej nazw, które odnoszą się do elementów istniejących w chwili powstania takiej definicji, bowiem takie włączenie do zakresu nazwy definiowanej może się odbyć tylko w drodze nowelizacji", jak to miało miejsce z wprowadzeniem 22 lipca $2000 \mathrm{r}^{34}$ do art. 69 pr. aut. nazwy „operator obrazu”. Ponieważ w 1994 r. operator obrazu był już znany w świecie filmowym, uznawanie przez „interpretatora” tekstu prawnego za „współtwórcę” utworu audiowizualnego (tj. „włączenie nazwy "operator obrazu" do zakresu nazwy definiowanej w inny sposób niż w drodze nowelizacji”) pomiędzy wejściem w życie ustawy o pr. aut. a 22 lipca 2000 r. byłoby bezprawne ${ }^{35}$.

Z powyższego można wyprowadzić wniosek, że de lege lata tezę o współtwórczym charakterze utworu audiowizualnego można w uzasadniony przepisami sposób ograniczyć - niezależnie od oceny okoliczności faktycznych działania konkretnych osób - do kręgu osób wymienionych w art. 69 pr. aut., tj. reżysera, operatora obrazu, twórcy adaptacji utworu literackiego, twórcy stworzonych dla utworu audiowizualnego utworów muzycznych lub słowno-muzycznych oraz twórcy scenariusza. Zatem uogólnione twierdzenie, że wszystkie utwory audiowizualne, w całości i wyłącznie, mają charakter współautorski - należy uznać za chybione, przez co nietrafne są wynikające z takiej tezy dalsze wnioski. Przykładem wywodu czynionego na gruncie takiej błędnej tezy jest przytoczony wyżej wyrok SA w Warszawie z 7 lutego 2014 r. ${ }^{36}$, powielający zasadniczo pogląd Czajkowskiej-Dąrowskiej ${ }^{37}$, w tym zwłaszcza słuszna będzie krytyka pozostającego w kolizji ze współtwórczościa, akcentowanego przez autorkę rzekomego zjawiska „dwóch naraz zestawów praw autorskich".

33 Zdaniem Choduń (2018: 209): „gdyby traktować to, co jest zawarte w definiensie definicji zakresowej niepełnej jako przykładowe niewyczerpujące wyliczenie elementów zakresu definiowanej nazwy, to trzeba by przyznać, że w takim przypadku redaktor tekstu nie panuje nad znaczeniem definiowanego wyrazu czy wyrażenia ani »na dziś«, ani »na przyszłość«. Powstaje zatem pytanie, czemu taka definicja miałaby służyć, skoro stosujący prawo mógłby bez żadnych ograniczeń niejako współtworzyć znaczenie wyrazu definiowanego".

${ }^{34}$ Ustawa z 9 czerwca 2000 r. o zmianie ustawy o prawie autorskim i prawach pokrewnych,

Dz. U. Nr 53, poz. 637.

35 Choduń (2018): 209.

${ }^{36}$ I ACa 452/13.

${ }^{37}$ Czajkowska-Dąbrowska (2011): 431. 
Opierając się na dokonanej przez Choduń wykładni art. 69 pr. aut., można zatem twierdzić, że utwory wkładowe twórców innych niż wymienieni w tym przepisie nie podlegają apriorycznemu ujęciu ich w ramach współtwórczości, przez co utwory te moga zachować swoją autonomię względem utworu audiowizualnego. Upada przecież wykładnia podtrzymująca koncepcję rzekomej „totalnej” współtwórczości w utworze audiowizualnym. Jednakże również wobec utworów twórców wymienionych w art. 69 pr. aut. możliwe staje się postrzeganie ich jako odrębnych od utworu audiowizualnego, a w każdym razie jako „niestapiających się bezpowrotnie” z owym utworem „jako całościa” i dających asumpt do analizy ich sytuacji prawnej. Przykładowo Damasiewicz stoi na stanowisku, że „scenariusz zasadniczo jest utworem przejściowym, nieprzeznaczonym do poznania w ustalonej pierwotnie formie, lecz $\mathrm{w}$ formie filmu” oraz że „Film jest rozpowszechnieniem scenariusza, wyłącznie w postaci wkładu twórczego do tego filmu"38.

\section{UTWÓR AUDIOWIZUALNY „JAKO CAŁOŚĆ" I SUMA WKŁADÓW TWÓRCZYCH NA TLE PRZEPISÓW PRAWA AUTORSKIEGO}

Nie można jednak w zupełności abstrahować od istnienia (nie tylko w teorii filmu czy w odczuciu widza) utworu audiowizualnego ,jako całości”. Explicite do takiego pojęcia nawiązuje jednak wyłącznie art. 70 ust. 1 pr. aut., gdy chodzi o domniemanie nabycia przez producenta na mocy określonych umów wyłącznych praw majątkowych do eksploatacji utworów wkładowych w ramach utworu audiowizualnego ,jako całości”.

Jednocześnie to także przepisy ustawy o pr. aut. zaznaczają dystynkcję pomiędzy ową całością a istniejącymi w jej ramach poszczególnymi wkładami. Domniemanie, o którym mowa w art. 70 ust. 1 pr. aut., zakłada eksploatację, a więc proces o charakterze ciagłym, polegający na korzystaniu z nowych bądź już istniejących utworów w ramach utworu audiowizualnego jako całości. Nie chodzi zatem tylko o włączenie utworu do „całości”, jaką ostatecznie stanie się utwór audiowizualny, lecz o zachowanie przez każdy włączony do niego utwór autonomii, tylko taki stan rzeczy pozwala bowiem na eksploatację wkładu. Gdyby natomiast utwory wkładowe miały nieodwracalnie „stapiać się” w jedną całość, nie można by w konsekwencji regulować ich odrębnych losów prawnych w takiej całości. Tymczasem zgodnie z art. 70 ust. 1 pr. aut. eksploatacja przez producenta konkretnego utworu wkładowego „w ramach utworu audiowizualnego jako całości” jest możliwa dopiero wówczas, gdy producent zawarł umowę o stworzenie takiego utworu albo o wykorzystanie utworu już istniejącego. Z kolei nie do obrony jest teza, że autorskie prawa majątkowe i osobiste do takiego utworu wkładowego z chwila jego włączenia do utworu audiowizualnego doznają unicestwienia, także z uwagi na art. 36 pr. aut., nieprzewidu-

${ }^{38}$ Damasiewicz (2015): 12, 15. 
jący takiego rozwiązania. Co więcej - art. 70 ust. 1 pr. aut. wyraźnie stanowi o „eksploatacji tych utworów w ramach” utworu audiowizualnego jako całości, podkreślając ich „równoległe” trwanie wobec takiego utworu.

Innym przepisem, który de lege lata akcentuje trwająca niezależnie od utworu audiowizualnego autonomię utworów wkładowych, jest art. 70 ust. $2^{1}$ pr. aut. Przyznanie „współtwórcom” utworu audiowizualnego prawa do wynagrodzenia z tytułu określonych rodzajów eksploatacji utworu audiowizualnego petryfikuje niezależne postrzeganie przez ustawodawcę tego utworu ,jako całości” i jako wiązki utworów wkładowych. Można by przecież z łatwościa sformułować taka potencjalną konstrukcję przepisów rozdz. 6, w której ex lege producent nabywałby autorskie prawa majątkowe nie tylko do „całości” utworu audiowizualnego, ale i do poszczególnych jego komponentów. Tymczasem przez 25 lat obowiązywania ustawy o pr. aut. konstrukcja rozdz. 6 nie zbliżała się nawet do tego „kompleksowego” rodzaju rozwiąania.

Dodatkowym argumentem na rzecz tezy o zachowaniu status quo przez utwory wkładowe, pomimo powstania utworu audiowizualnego ,jako całości”, jest wprowadzony z dniem 1 maja 2004 r. ${ }^{39}$ art. 41 ust. 5 pr. aut. ${ }^{40}$ Zgodnie z tym przepisem twórca utworu wykorzystanego lub włączonego do utworu audiowizualnego, po powstaniu nowych pól eksploatacji utworów, nie może bez ważnego powodu odmówić udzielenia zezwolenia na korzystanie z tego utworu w ramach utworu audiowizualnego na polach eksploatacji nieznanych w chwili zawarcia umowy. Ustawodawca zatem potwierdza trwanie nie tylko utworów, ale także praw autorskich do nich po stronie twórców, pomimo prowadzonej w założeniu przez dłuższy już czas eksploatacji utworu audiowizualnego.

Ponadto art. 36 pkt 4 pr. aut., wprawdzie nie posługując się terminem „współtwórca”, odnosi czas trwania autorskich praw majątkowych do utworu audiowizualnego nie do daty np. rozpowszechnienia, lecz do śmierci najpóźniej zmarłej z wymienionych osób: głównego reżysera, autora scenariusza, autora dialogów, kompozytora muzyki skomponowanej do utworu audiowizualnego. Przepis ten nie odnosi się do zjawiska współtwórczości, tę problematykę bowiem - gdy chodzi o wygaśnięcie autorskich praw majątkowych - reguluje art. 36 pkt 1 pr. aut., natomiast nie niweczy trwania autorskich praw majątkowych do utworów składających się na utworów audiowizualny, chociaż eksponuje tylko wybranych uprawnionych twórców. Jest więc przewidziane przez ustawę, że pomimo wygaśnięcia autorskich praw majątkowych do utworu audiowizualnego ,jako całości” autorskie prawa majątkowe co najmniej do niektórych utworów wkładowych trwać będą nadal.

Z powyższego wynika, że ustawodawca wyraźnie zaznaczył prawną odrębność wkładów twórczych, poniekąd zarazem „wtopionych” w utwór audiowizualny, do tego pojmowany ,jako całość”. Wprawdzie przy analizie konkretnego rodzaju utworu nieodzowne staje się sięganie do wiedzy specjalistycznej z za-

39 Ustawa z 1 kwietnia 2004 r. o zmianie ustawy o prawie autorskim i prawach pokrewnych, Dz. U. Nr 91, poz. 869.

40 Zob. Sokołowska (2013): 129-177. 
kresu powstawania takiego utworu, to jednak ustawodawca dysponuje pełna swobodą odnośnie do ustawowego ujęcia specyfiki każdego utworu. Należy zatem uwzględniać dorobek filmoznawstwa, które zresztą akceptuje autonomię zarówno utworu audiowizualnego „jako całości”, jak i autonomię składających się nań wkładów. Jednocześnie wykładnia przepisów ustawy o pr. aut. musi zostać podporządkowana jedynie ich aktualnemu brzmieniu.

Tak zatem jak de lege lata nie jest uzasadnione podtrzymywanie tezy o pierwotnym przysługiwaniu całości autorskich praw majątkowych do utworu audiowizualnego jako całości producentowi, tak i brak podstawy do negowania znaczenia przepisów potwierdzajacych „istnienie utworów w utworze”, jak to czyni np. przytaczany wyrok Sądu Apelacyjnego w Warszawie z 7 lutego 2014 r. ${ }^{41}$ Doszukiwanie się w tym przypadku zamiarów czy intencji ustawodawcy na rzecz poglądu odmiennego należy uznać za zbędne z uwagi na wyraźne brzmienie przepisów, które zresztą nie kolidują ani z istnieniem w przepisach prawa (art. 70 ust. 1 pr. aut.), ani w odczuciu społecznym utworu audiowizualnego ,jako całości”.

Można przypomnieć, co również podkreśla Aurelia Nowicka, że „celem odstapienia przez ustawodawcę od poprzedniej, utrwalonej w prawie polskim regulacji czyniacej producenta podmiotem pierwotnie uprawnionym z tytułu autorskich praw majątkowych do utworu audiowizualnego był zamiar wzmocnienia sytuacji prawnej twórców (współtwórców) tych utworów”"42. Również Anna Wojciechowska, odnosząc się do nowelizacji ustawy o pr. aut. z 2000 r., uważa, że „nowa regulacja, wzmacniająca status prawny twórców w warunkach dominującej pozycji producenta, była zgodna z podstawowym modelem ochrony w państwach członkowskich Unii Europejskiej i świadczyła o przesunięciu priorytetów w systemie ochrony utworu audiowizualnego w Polsce" 43.

\section{ZAKOŃCZENIE}

Powyższe rozważania, choć oczywiście nie wyczerpuja poruszonych zagadnień, prowadzą do wniosku, że od lat dokonywane w doktrynie i orzecznictwie próby „wywłaszczania” twórców utworów wkładowych do utworu audiowizualnego z ich praw nie znajdują właściwego uzasadnienia. Główną ich podstawa jest bowiem przyjęta a limine teza o generalnie współtwórczym charakterze utworu audiowizualnego, co nie wytrzymuje krytyki ani ze względów prawnych, ani faktycznych. Pozostaje zatem postawić pytanie o faktyczny cel podtrzymywania powyższego poglądu.

Tu z kolei można zaryzykować twierdzenie, iż chodzi o względy natury ekonomicznej, a przykładem na potwierdzenie tego poglądu sa wytaczane przez organizacje zbiorowego zarządzania prawami autorskimi i prawami pokrewnymi postępowania sądowe, związane z brakiem właściwego stosowa-

\footnotetext{
41 Wyrok SA w Warszawie z 7 lutego 2014 r., I ACa 452/13.

42 Nowicka (2017): 133.

43 Wojciechowska (2015): 27.
} 
nia przez operatorów sieci kablowych art. $21^{1}$ ust. 1 pr. aut. Podnoszony jest wówczas przez operatorów argument o braku uprawnienia twórców wkładów do utworu audiowizualnego do wypłaty należnego im wynagrodzenia z tytułu reemisji utworu audiowizualnego na podstawie art. 70 ust. $2^{1}$ pr. aut. Wiąże się to ściśle także z kwestionowaniem przez operatorów sieci kablowych czynnej legitymacji procesowej po stronie organizacji zbiorowego zarządzania reprezentujących twórców poszczególnych wkładów do utworu audiowizualnego, np. Stowarzyszenia Autorów ZAiKS i Stowarzyszenia Filmowców Polskich. Dotyczy to w szczególności tzw. roszczenia informacyjnego, w ramach którego stowarzyszenia uzyskują dane dotyczące wykorzystywania w utworach audiowizualnych - utworów słownych, muzycznych, słowno-muzycznych i choreograficznych ${ }^{44}$ bądź twórczości reżyserów i scenarzystów ${ }^{45}$.

O skali płaszczyzny finansowej, na której może toczyć się wspomniana debata, mogą świadczyć aktualne dane liczbowe: według ustaleń Polskiej Izby Komunikacji Elektronicznej z lutego 2019 r. 10 głównych operatorów sieci kablowych świadczy usługi dla blisko $4 \mathrm{mln}$ abonentów, obejmując swym zasięgiem ok. 89\% rynku ${ }^{46}$. Pierwszy w rankingu operatorów (UPC Polska - 31,9\% rynku) osiagnał na koniec 2018 r. przychody w wysokości 1,59 mld zł ${ }^{47}$, a drugi (Vectra - 22,3\% rynku) uzyskał w 2017 przychody w wysokości blisko $737 \mathrm{mln} \mathrm{zł}^{48}$.

\section{Dorota Sokotowska}

Uniwersytet Szczecinski

dorota.sokolowska@usz.edu.pl

https://orcid.org/0000-0001-9659-842X

Czajkowska-Dąbrowska, M. (2011). Przepisy szczególne dotyczące utworów audiowizualnych, [w:] J. Barta, R. Markiewicz R. (red.), Prawo autorskie i prawa pokrewne. Komentarz. Warszawa: $419-454$.

Barta, J., Markiewicz, R. (2016). Prawo autorskie. Warszawa.

Błeszyński, J. (1995). Wynagrodzenie autorskie w świetle art. 70 ust. 3 i 5 ustawy o prawie autorskim i prawach pokrewnych. Przegląd Ustawodawstwa Gospodarczego 8: 2-7.

Błeszyński, J. (1998). Obowiązek i charakter zatwierdzania przez Komisję Prawa Autorskiego tabel wynagrodzeń autorskich. Przegląd Ustawodawstwa Gospodarczego 3: 2-15.

Błeszyński, J. (2009). Glosa do uchwały składu siedmiu sędziów Sądu Najwyższego - Izba Cywilna z 25 listopada 2008 r., III CZP 57/2008. Przegląd Ustawodawstwa Gospodarczego 5: 12-28.

Błeszyński, J., Błeszyńska-Przybylska, M., Błeszyński, M. (2019). Status prawny utworów wykorzystanych w utworach audiowizualnych. Uwagi do wyroku Sądu Apelacyjnego w Warszawie z 17.08.2017 r., I ACa 837/16, [w:] K. Szczepanowska-Kozłowska, I. Matusiak, Ł. Żelechowski

${ }^{44}$ Dotyczy Stowarzyszenia Autorów ZAiKS - por. wyrok SO w Gdańsku z 24 marca 2014 r., I C 719/13, Lex nr 2190050.

${ }^{45}$ Dotyczy Stowarzyszenia Filmowców Polskich - por. wyrok SA w Szczecinie z 9 listopada 2017 r., I ACa 473/17, Lex nr 2488260. Zob. jednak zezwolenie Ministra Kultury i Dziedzictwa Narodowego, niepotwierdzające takiego uprawnienia SFP (załącznik do obwieszczenia MKiDN z 26 marca 2009 r., M.P. Nr 21, poz. 270), obowiązujące do 19 lipca 2018 r.

${ }^{46}<$ http://www.pike.org.pl/index/ranking>

$47<$ https://www.wirtualnemedia.pl/artykul/upc-polska-wyniki-2018-rok-liczba-abonentow-przychody>

${ }^{48}<\mathrm{http}: / /$ rpkom.pl/artykul/1372939.html> 
(red.), Opus auctorem laudat. Księga jubileuszowa dedykowana Profesor Monice Czajkowskiej-Dąbrowskiej. Warszawa: 36-72.

Bocheńska, J. (1966). Obraz filmowy jako znak, [w:] A. Jackiewicz (red.), Wstęp do badania dzieła filmowego. Warszawa: 188-208.

Bukowski, M. (2015). Przepisy szczególne dotyczące utworów audiowizualnych, [w:] D. Flisak (red.), Prawo autorskie i prawa pokrewne. Komentarz Lex. Warszawa: 915-940.

Choduń, A. (2018). Aspekty językowe derywacyjnej koncepcji wykładni prawa. Szczecin.

Damasiewicz, A. (2015). Czy film fabularny jest sposobem rozpowszechnienia scenariusza filmowego (w rozumieniu ustawy o prawie autorskim i prawach pokrewnych)? Zeszyty Naukowe Uniwersytetu Jagiellońskiego. Prace z Prawa Własności Intelektualnej 3(129): 5-17.

Hendrykowski, M. (1988). Autor jako problem poetyki filmu. Poznań.

Hendrykowski, M. (1991). Dzieło filmowe i jego autor. Poznań.

Hendrykowski, M. (2014). Autorstwo utworu audiowizualnego - substancja i struktura. Images. The International Journal of European Film, Performing Arts and Audiovisual Communication 15(24): 91-98.

Ingarden, R. (1952). Studia z estetyki Tom 2. Warszawa.

Ingarden, R. (1966). Studia z estetyki. Tom 1. Warszawa.

Kakareko, K. (2019). Status prawny twórców utworów filmowych. Poznań.

Ledóchowski, A. (1966). Estetyczna i informacyjna funkcja dzieła filmowego (Teoria 'sygnałów'), [w:] A. Jackiewicz (red.), Wstęp do badania dzieła filmowego. Warszawa: 77-114.

Nowak-Gruca, A. (2018). Przedmiot prawa autorskiego (utwór) w ujęciu kognitywnym. Warszawa.

Nowicka, A. (2017). Utwory audiowizualne, [w:] J. Barta (red.), System prawa prywatnego. Tom 13: Prawo autorskie. Warszawa: 130-137.

Plisiecki, J. (2005). Film i sztuki tradycyjne. Lublin.

Sieńczyło-Chlabicz, J., Banasiuk, J. (2011). Twórcy dzieł uprzednio stworzonych a współtwórczość utworu audiowizualnego, [w:] K. Lewandowski (red.), Utwór audiowizualny. Zakres pojęcia i ochrony prawnej. Poznań: 75-96.

Sokołowska, D. (2011). Współtwórczość a utwór audiowizualny, [w:] K. Lewandowski (red.), Utwór audiowizualny. Zakres pojęcia i ochrony prawnej. Poznań: 59-74.

Sokołowska, D. (2013). Korzystanie z utworów na tle art. 41 ust. 5 ustawy o prawie autorskim i prawach pokrewnych, [w:] D. Sokołowska (red.), Dzieła osierocone. Korzystanie z dzieł osieroconych w świetle Dyrektywy Parlamentu Europejskiego i Rady 2012/28/UE z 25 października 2012. Poznań: 129-177.

Sokołowska, D. (2015). Struktura utworu audiowizualnego i status twórców utworów wkładowych - glosa do uchwały składu 7 sędziów Sądu Najwyższego z 25.11.2008 r. (III CZP 57/2008). Glosa 1: 86-103.

Ślęzak, P. (2008). Wynagrodzenie twórców filmowych i artystów wykonawców z tytułu rozpowszechniania utworu. Państwo i Prawo 63(10): 85-94.

Świętczak, M. (2019). Przepisy szczególne dotyczące utworów audiowizualnych, [w:] W. Machała, R.M. Sarbiński (red.), Prawo autorskie i prawa pokrewne. Komentarz. Warszawa: 10531122 .

Wojciechowska, A. (2015). Ewolucja modelu autorstwa filmowego w prawie polskim. Zeszyty Naukowe Uniwersytetu Jagiellońskiego. Prace z Prawa Własności Intelektualnej 2(128): 19-29.

\section{ON THE PROPERTIES OF AN AUDIOVISUAL WORK 'AS A WHOLE'}

\section{Summary}

One of the controversial issues in copyright law is how an audiovisual work is to be defined and understood. Part of the jurisprudence and doctrine is of the opinion that an audiovisual work constitutes a whole, it is a single work and not a collection of various so-called 'contribution' works. The article presents the thesis on maintaining the status quo with regard to contribution works, especially from the perspective of Article 70 para. 2.1 of the Act on Copyright and Related Rights of 4 February 1994.

Keywords: copyright; audiovisual work; contribution 